Anna A. Janowska

\title{
WOLNY DOSTĘP DO WIEDZY: OTWARTE ZASOBY NAUKOWE I EDUKACYJNE W SPOKECZEŃSTWIE OPARTYM NA WIEDZY
}

\section{Wprowadzenie}

„Wolny” czy inaczej „otwarty” dostęp to pojęcie, które zaczęło być przedmiotem dyskusji, również naukowej, wraz z rozwojem internetu. Mówi się o wolnym, otwartym dostępie do dóbr kultury, do zasobów wiedzy i zasobów edukacyjnych. Sam internet stał się niejako inspiracją dla takich zjawisk, jako że jest medium, które kojarzy się właśnie z otwartością, będącą właściwie jego immanentną cechą. Pozwala on nie tylko na szybką wymianę informacji i ma nieskończony zasięg, spowodował również drastyczny spadek kosztów kopiowania informacji, a także jej rozpowszechniania. W połączeniu z malejącymi wciąż cenami sprzętu komputerowego, a także stałego dostępu do sieci powstało w związku z tym środowisko, w którym zaczęły się rozwijać różne oddolne inicjatywy, podejmowane często przez pasjonatów, ludzi niepobierających za swoją pracę wynagrodzenia.

Do inicjatyw takich należy otwarty dostęp do nauki, a ściśle mówiąc do publikacji naukowych, zwany open access (OA). Coraz więcej takich treści zaczęło być dostępnych online bez żadnych ograniczeń korzystania, a także bez opłat, co oczywiście zagroziło pozycji i modelowi biznesowemu wielkich, międzynarodowych wydawnictw mających w świecie „materialnym” monopol na wydawanie tekstów naukowych. Ponieważ zaś ruch ten zaczął być wspierany przez naukowców o ugruntowanej pozycji w środowisku, stał się powoli realną alternatywą dla systemu tradycyjnego.

Drugim, pokrewnym open access ruchem jest ruch otwartej edukacji, czyli open educational resources (OER), polegający na tworzeniu i rozpowszechnianiu materiałów edukacyjnych, do których dostęp jest darmowy i które można dowolnie wykorzystywać. Ze względu na fakt, że jest on tworzony niejako poza systemem rynkowym, bo dzięki pracy wolontariuszy, oraz finansowany bądź ze środków publicznych, bądź też z zasobów różnych fundacji, nie wzbudza tak wielkich kontrowersji jak open access. 
Oba te zjawiska są stosunkowo świeże, dlatego warto im się przyjrzeć w kontekście ekonomiczno-społecznym. Przedmiotem artykułu są więc otwarte zasoby naukowe i edukacyjne oraz rola, jaką mogą spełniać w społeczeństwie opartym na wiedzy. Poruszone będą zarówno ekonomiczne, jak i społeczne aspekty obu tych nowych zjawisk.

\section{Open access i open education - wprowadzenie do zagadnienia}

Definicje open access w literaturze są dość spójne, a punktem wyjścia do ich opracowania jest definicja zawarta w Budapest Open Access Initiative (BOAI). Dokument ten został sformułowany w grudniu 2001 r. na spotkaniu zorganizowanym przez Open Society Institute, które uważane jest za formalny początek zjawiska open access $^{1}$. Jest on rozumiany tutaj, po pierwsze, jako możliwość udostępniania przez autorów online artykułów recenzowanych, a także tekstów nierecenzowanych w celu uzyskania komentarzy, bądź też poinformowania innych o ważnych odkryciach. Po drugie, polega na dostępności tekstów w internecie, wraz z możliwością ich czytania, ściągania, kopiowania, redystrybucji, drukowania, przeszukiwania, linkowania do pełnych tekstów artykułów, indeksowania ich, umieszczania jako danych w oprogramowaniu, a także wykorzystywaniu w jakimkolwiek innym, zgodnym z prawem celu, bez żadnych barier finansowych, prawnych czy też technicznych, poza uzyskaniem dostępu do internetu jako takiego. Jedyne prawo, jakie przysługuje tutaj autorom, to prawo do czuwania nad integralnością dzieła oraz prawo do autorstwa (umieszczanie nazwiska w przypadku cytowania) ${ }^{2}$. Open access dotyczy więc darmowego dostępu do dzieł, które mają postać scyfryzowaną, czyli są dostępne w internecie, a chodzi tutaj wyłącznie o teksty naukowe, definicja nie obejmuje bowiem beletrystyki, artykułów prasowych, poradników i tym podobnych.

Budapeszteńska definicja została rozszerzona na spotkaniu, które odbyło się w kwietniu 2003 r. w Howard Hughes Medical Institute w Maryland. Sformułowano na nim Bethesda Statement on Open Access Publishing, w którym pierwotna definicja open access została uzupełniona o dwa stwierdzenia: zamiast szerszej możliwości „wykorzystywania w jakimkolwiek innym, zgodnym z prawem celu” zaproponowano

1 C.W. Bailey, What Is Open Access?, w: Open Access: Key Strategic, Technical and Economic Aspects, red. N. Jacobs, Chandos Publishing, Oxford 2006, s. 13-26, http://www.chandospublishing.com/catalogue/record_detail.php?recordID $=103$ [dostęp 29.09.2013].

2 Budapest Open Access Initiative|Read the Budapest Open Access Initiative, http://www.budapestopenaccessinitiative.org/read [dostęp 29.09.2013]. 
zawężenie uprawnień. Otóż dokumenty zakwalifikowane jako open access mogą być „kopiowane wyłącznie w małych nakładach i tylko na osobisty użytek”3. Druga zmiana dodaje możliwość tworzenia i rozpowszechniania dzieł pochodnych.

Kolejny dokument, Berlin Declaration on Open Access, sporządzony po spotkaniu w Max Planck Society, które odbyło się również w 2003 r., podaje dokładnie taką samą definicję open access, jaką przyjęto w Maryland. Co więcej, w obydwu dokumentach zwrócono uwagę na trzy istotne warunki, jakie musi spełniać tekst, aby można go było uznać za udostępniony w trybie open access:

- artykuł musi być rozpowszechniony w wolnym dostępie, co oznacza, że użytkownik nie może ponosić żadnych kosztów dostępu, nie można też nikomu takiego dostępu ograniczyć;

- autorzy lub posiadacze praw do artykułu dają stronie trzeciej, z góry i na czas nieokreślony, prawo do używania, kopiowania lub rozpowszechniania artykułu, pod warunkiem zachowania zasady przypisania autorstwa (właściwe opisanie przy cytowaniu);

- artykuł musi być po napisaniu zdeponowany w całości, w odpowiedniej formie elektronicznej, w co najmniej jednym szeroko i międzynarodowo uznanym repozytorium open access, które zobowiązane jest do zagwarantowania wolnego dostępu do dzieła i do jego archiwizacji ${ }^{4}$.

Peter Suber zwraca uwagę na dwie cechy charakterystyczne dokumentów udostępnianych w wolnym dostępie, czyli jako open access. Podkreśla on, że system ten znosi „bariery ceny” (np. subskrypcję, która stanowi podstawowy model udostępniania prac w świecie nauki) i „bariery uprawnień” (ograniczenia prawne co do wykorzystywania tekstów w trybie znacznie szerszym niż gwarantuje to obowiązujące prawo autorskie) do dzieł, od których nie przysługują tantiemy ${ }^{5}$. Oznacza to, że są one dostępne $\mathrm{z}$ „minimalnymi ograniczeniami wykorzystania” (np. przypisanie autorstwa $)^{6}$.

Jeśli chodzi o „otwarte zasoby edukacyjne”, jest to zjawisko, które wywodzi się $\mathrm{z}$ ruchu na rzecz wolnej nauki i polega na otwartym dostępie do materiałów edukacyjnych oraz na zapewnieniu odbiorcom swobody ich wykorzystywania. Działania tego ruchu opierają się na idei, że „wiedza całego świata jest dobrem publicznym, dlatego każdy powinien mieć swobodę wykorzystywania, dostosowywania do swoich

3 J.A. Rankin, S.G. Franklin, Open Access Publishing, ,Emerging Infectious Diseases” July 2004, Vol. 10, No. 7 , s. 5.

4 Ibidem, s. 6.

5 Tzw. royalty-free literature.

6 P. Suber, Open Access Overview (definition, introduction), http://legacy.earlham.edu/ peters/fos/overview.htm [dostęp 29.09.2013].

7 Open educational resources (OER). 
potrzeb, ulepszania i rozpowszechniania materiałów edukacyjnych bez ograniczeń, by uczynić edukację zarówno bardziej dostępną, jak i bardziej skuteczną"». Samo sformułowanie zostało użyte po raz pierwszy w czasie konferencji UNESCO w 2012 r. na temat otwartych programów edukacyjnych w państwach rozwijających się. Otwartymi zasobami edukacyjnymi nazwano tam materiały edukacyjne (np. plany lekcji, testy, programy nauczania, moduły szkoleniowe, symulacje, zadania itd.), które są dostępne w otwarty sposób i które można powtórnie wykorzystać, dostosować do swoich potrzeb oraz przekazać do wykorzystania innym ${ }^{9}$. Podobną definicję sformułowała polska Koalicja Otwartej Edukacji: otwarte zasoby edukacyjne to materiały, które są publicznie dostępne w internecie (bez kontroli dostępu), opublikowane wraz z prawem do dalszego wykorzystania (w tym celu zalecane jest stosowanie tzw. wolnych licencji) i najczęściej rozwijane w otwarty sposób ${ }^{10}$. Należą do nich plany nauczania, materiały do zajęć, podręczniki, filmy wideo, aplikacje multimedialne, podcasty i inne narzędzia stosowane w nauczaniu oraz uczeniu $\operatorname{się}^{11}$. Według aktualnej definicji OECD otwarte zasoby edukacyjne to scyfryzowane materiały oferowane $\mathrm{w}$ wolnym i otwartym dostępie nauczycielom, studentom oraz osobom uczącym się samodzielnie, które można wielokrotnie wykorzystywać do nauczania, uczenia się oraz prowadzenia badan ${ }^{12}$.

Warto podkreślić, że do inicjatyw należących do obszaru otwartej edukacji należą różne projekty, realizowane zupełnie niezależnie, często na zasadzie tzw. produkcji partnerskiej ${ }^{13}$, bez żadnego odgórnego planu czy też dozoru. Można do nich zaliczyć projekty zarówno o dużej, jak i małej skali, które są inicjowane przez instytucje oraz oddolnie, jako działania społecznościowe. Jedną z pierwszych inicjatyw tego rodzaju, o pochodzeniu społecznościowym, jest Wikipedia, która została uruchomiona w $2001 \mathrm{r}$. W 2006 r. tygodnik „Time” nazwał ją kosmicznym kompendium wiedzy ${ }^{14}$ : według stanu z września 2013 r. zawierała ona ponad 29 mln artykułów, zaś redagowało ją

8 K. Grodecka, K. Śliwowski, Przewodnik po otwartych zasobach edukacyjnych, Koalicja Otwartej Edukacji, Warszawa 2012, s. 7, http://koed.org.pl/wp-content/uploads/2012/03/OZE_przewodnik_v4.pdf

9 S. Gurell, Wprowadzenie do otwartych zasobów edukacyjnych, Koalicja Otwartej Edukacji, http://www. kpbc.ukw.edu.pl/Content/40051/gurell.pdf

10 K. Grodecka, K. Śliwowski, op.cit., s. 9.

11 N. Butcher, A Basic Guide to Open Educational Resources (OER), red. A. Kanwar, S. Uvalić-Trumbić, UNESCO, Vancouver, Paris 2011, s. 5.

12 Giving Knowledge for Free. The Emergence of Open Educational Resources, OECD, Paris 2007, s. 32, http://www.oecd.org/edu/ceri/38654317.pdf

13 Produkcja partnerska, społeczna (peer production) to inicjatywy oddolne, podejmowane dobrowolnie przez ludzi, których łączy wspólna pasja, wspólny cel. Przykładem takiego projektu jest Wikipedia. Por. Y. Benkler, Bogactwo sieci: jak produkcja społeczna zmienia rynki i wolność, Wydawnictwa Akademickie i Profesjonalne, Warszawa 2008, s. 22.

14 L. Grossman, You - Yes, You - Are Time's Person of the Year, „Time” December 25, 2006, http://content.time.com/time/magazine/article/0,9171,1570810,00.html [dostęp 29.09.2013]. 
około 1,7 mln osób ${ }^{15}$. Według Tapscotta i Williamsa jej największą słabością jest to, iż każdy z uczestników może stwierdzić, że jest ekspertem w dowolnej dziedzinie ${ }^{16}$. Chociaż nie jest ona wolna od błędów, to analiza porównawcza dokonana w magazynie „Nature” wykazała, że Wikipedia dorównuje wiarygodnością Britannice ${ }^{17}$. Jej siłą jest możliwość natychmiastowego korygowania błędów przez niezhierarchizowaną, a więc wolną od obciążeń relacji służbowych społeczność, co wpływa w sposób pozytywny na wiarygodność sieciowej encyklopedii jako źródła informacji. Kolejną zaletą jest bogactwo wersji językowych, olbrzymia liczba haseł i - przede wszystkim - otwartość (darmowość). Można ją więc uznać za przykład międzynarodowego projektu $\mathrm{z}$ dziedziny open education, gromadzi ona bowiem ogromne zasoby przydatnych informacji dla studentów i wykładowców ${ }^{18}$.

Z kolei inspiracją dla działań realizowanych przez instytucje, zarówno rządowe, jak i pozarządowe, był projekt OpenCourseWare oraz OpenCourseWare Consortium stworzony przez Massachusetts Institute of Technology w 2000 r. Do konsorcjum przystąpiło już ponad 200 uczelni wyższych i innych organizacji z całego świata ${ }^{19}$, które udostępniają w sumie ponad 2150 kursów. Według danych z 2012 r. skorzystało z nich już ponad 125 mln użytkowników ${ }^{20}$.

Jak to już zostało stwierdzone wyżej, ruch otwartych zasobów edukacyjnych jest przedmiotem troski takich organizacji, jak UNESCO czy OECD, jest to więc niewątpliwie projekt o światowym zasięgu i znaczeniu. W 2008 r. powstała nawet Deklaracja Otwartej Edukacji, będąca jednym z kluczowych dokumentów określających cele i metody ruchu otwartych zasobów edukacyjnych. Była ona efektem spotkania przedstawicieli instytucji naukowych, administracji państwowej, organizacji pozarządowych, a także nauczycieli i autorów materiałów edukacyjnych, mającego na celu promocję otwartych zasobów, technologii oraz nauczania praktyk w zakresie edukacji ${ }^{21}$.

W roku 2012, na Światowym Kongresie Otwartych Zasobów Edukacyjnych zorganizowanym przez UNESCO, przyjęto Paryską Deklarację otwartych zasobów edukacyjnych $^{22}$. Podkreśla ona konieczność przyjmowania przez rządy państw członkowskich

15 Wikipedia Statistics - Tables - All languages, http://stats.wikimedia.org/EN/TablesWikipediaZZ.htm [dostęp 29.09.2013].

16 D. Tapscott, Wikinomia: o globalnej współpracy, która zmienia wszystko, Cyberkultura, Internet, Spoleczeństwo, Warszawa, Wydawnictwa Akademickie i Profesjonalne, Warszawa 2008, s. 115.

17 Ibidem, s. 117

18 S. Gurell, op.cit.

19 Giving Knowledge..., op.cit., s. 43.

20 Dane z 2012 r., por. Our History|MIT OpenCourseWare|Free Online Course Materials, http://ocw.mit. edu/about/our-history/ [dostęp 29.09.2013].

21 K. Grodecka, K. Śliwowski, op.cit., s. 10.

22 What is the Paris OER Declaration? United Nations Educational, Scientific and Cultural Organization, UNESCO, Communication and Information, http://www.unesco.org/new/index.php?id=64395\&L=0 [dostęp 29.09.2013]. 
strategii wspierania i tworzenia otwartych zasobów edukacyjnych finansowanych z pieniędzy publicznych, ze szczególnym uwzględnieniem ich wielojęzyczności i różnych kontekstów kulturowych, a także tworzenia aliansów strategicznych między takimi sektorami, jak edukacja, przemysł, biblioteki, media i sektor telekomunikacyjny ${ }^{23}$.

Jeśli chodzi o Europę, to wspierane są tutaj takie europejskie programy, jak ARIADNE, w ramach którego przygotowywane są narzędzia i metodologie do tworzenia programów pedagogicznych, do zarządzania nimi i do ich wykorzystywania w praktyce ${ }^{24}$. Z kolei bogate otwarte zasoby edukacyjne można znaleźć w bazie MORIL, która jest inicjatywą EADTU, czyli Europejskiej Instytucjonalnej Sieci na rzecz Otwartej Edukacji Wyższej ${ }^{25}$.Ta ostatnia oraz dwie inne inicjatywy europejskie - OpenLearn, uruchomiona przez Open University UK, i OpenER, stworzona przez Open Universiteit Nederland, funkcjonują jako uniwersytety proponujące kształcenie na odległość. Oferują one materiały przede wszystkim dla osób starszych i takich, które chcą się same kształcić. Wiele europejskich instytucji oferuje również w wolnym dostępie materiały niebędące wykładami. Są to filmy z zajęć, seminariów, linki, studia przypadku, symulacje, modele i rozmaite teksty uzupełniające.

Do projektów z dziedziny OER możemy również zaliczyć Google Books Search - inicjatywę firmy Google, której celem jest zeskanowanie i udostępnienie wszystkich książek, jakie się ukazują na świecie. Ze względu na ograniczenia autorsko-prawne możliwe jest udostępnianie w całości tylko części z nich, spora liczba prezentowana jest we fragmentach. Analogiczną inicjatywą jest Projekt Gutenberg, zapoczątkowany przez Amerykanina Michaela S. Harta, twórcę książki elektronicznej. Jest on realizowany na zasadach produkcji partnerskiej i ma na celu cyfryzację i archiwizację dóbr kultury, stanowiąc w ten sposób zachętę do tworzenia i rozpowszechniania książek elektronicznych ${ }^{26}$.

Dokumenty naukowe, podobnie jak edukacyjne, które można uznać za przynależne do systemu open access i open education, muszą spełniać podstawowe warunki tzw. open content (wolnej, otwartej treści). Termin ten został zaproponowany przez Davida Wileya w 1998 r. i odnosi się do utworów publikowanych na tzw. open content

23 Déclaration de Paris sur les REL 2012, 2012, http://www.unesco.org/new/fileadmin/MULTIMEDIA/ $\mathrm{HQ} / \mathrm{CI} / \mathrm{CI} / \mathrm{pdf} /$ Events/French_Paris_OER_Declaration.pdf

24 About Ariadne, http://www.ariadne-eu.org/ [dostęp 29.09.2013].

25 EADTU powstała w $1987 \mathrm{r}$., w jej skład wchodzą uniwersytety proponujące otwartą edukację i edukację zdalną, narodowe konsorcja łączące tradycyjne uniwersytety i członków spoza Europy. Należy do niej obecnie około 200 uniwersytetów, w których studiuje $3 \mathrm{mln}$ studentów; por. About EADTU, http://www. eadtu.eu/about-eadtu.html [dostęp 29.09.2013].

26 Project Gutenberg, Wikipedia, the free encyclopedia, September 30, 2013, http://en.wikipedia. org/w/index.php?title=Project_Gutenberg\&oldid $=561202664$ 
license $^{27}$ (licencjach wolnej treści). Nawiązuje on bezpośrednio do pojęcia open source ${ }^{28}$ oraz free software ${ }^{29}$, a więc dwóch mających wspólne korzenie ruchów w dziedzinie tworzenia i rozpowszechniania oprogramowania komputerowego. Były to pierwsze projekty o charakterze masowym realizowane w sieci przez grupy użytkowników, których celem było tworzenie dóbr i udostępnianie ich odbiorcom zarówno bez barier ceny, jak i uprawnień.

Wiley definiuje open content jako treść, co do której uprawnienia autorskie wykraczają poza oferowane przez tradycyjnie pojmowane i obowiązujące prawo autorskie. Szczegółowo określa je tzw. 5R Framework (tab. 1).

Tabela 1.5R Framework - 5 uprawnień użytkowników open content

\begin{tabular}{|l|l|}
\hline \multicolumn{1}{|c|}{ Rodzaj uprawnienia } & \multicolumn{1}{c|}{ Opis } \\
\hline Retain - gromadzenie & $\begin{array}{l}\text { prawo do robienia, posiadania i kontrolowania kopii treści (np. ściąganie, powielanie, } \\
\text { składowanie i zarządzanie) }\end{array}$ \\
\hline $\begin{array}{l}\text { Reuse - ponowne } \\
\text { wykorzystanie }\end{array}$ & $\begin{array}{l}\text { prawo do ponownego użycia treści w formie niezmienionej (np. tworzenie kopii zapasowej } \\
\text { zawartości) }\end{array}$ \\
\hline $\begin{array}{l}\text { Revise - możliwość } \\
\text { modyfikacji }\end{array}$ & $\begin{array}{l}\text { prawo do wprowadzania zmian, dostosowywania, modyfikowania lub zmieniania samej } \\
\text { zawartości (np. tłumaczenie treści na język obcy) }\end{array}$ \\
\hline $\begin{array}{l}\text { Remix - możliwość } \\
\text { tączenia treści }\end{array}$ & $\begin{array}{l}\text { prawo do łączenia treści pochodzącej z różnych materiałów, w formie oryginalnej lub } \\
\text { zmienionej, w celu stworzenia czegoś nowego (np. włączenie treści w tzw. mashup) }\end{array}$ \\
\hline $\begin{array}{l}\text { Redistribute } \\
\text { - rozpowszechnianie }\end{array}$ & $\begin{array}{l}\text { prawo do dzielenia się z innymi kopiami oryginalnych treści, treści z wprowadzonymi przez } \\
\text { siebie zmianami, sporządzonymi na ich podstawie remiksami (np. możliwość przekazania } \\
\text { kopii treści znajomemu) }\end{array}$ \\
\hline
\end{tabular}

Źródło: Defining the "Open” in Open Content, http://opencontent.org/definition/ [dostęp 8.10.2014].

5R Framework oznacza, że treści, które zostały upowszechnione, np. w internecie, mogą być swobodnie wykorzystywane, modyfikowane, a także dalej rozpowszechniane, co kłóci się z obowiązującym obecnie systemem prawa autorskiego, czy też copyright $^{30}$. Zasady te dotyczą recenzowanych prac naukowych, książek, artykułów,

27 OpenContent, 28 stycznia 1999, http://web.archive.org/web/19990128224600/http://www.opencontent.org/home.shtml [dostęp 30.09.2013].

28 Open Source to oprogramowanie o tzw. otwartym kodzie (kod używany do tworzenia programów komputerowych). Nie oznacza jednak wyłącznie dostępności kodu oprogramowania, jest to oprogramowanie, „którego licencja pozwala na legalne i nieodpłatne kopiowane, zarówno kodu wynikowego, jak i źródłowego oraz na dowolne modyfikacje kodu źródłowego", por. Open Source - otwarte oprogramowanie, http:// www.opensource.ite.pl/page/zalozenia.html [dostęp 29.09.2013].

29 Free software oznacza oprogramowanie, które jest powszechnie dostępne i którego można swobodnie używać, zgodnie z zasadami tzw. powszechnej licencji publicznej GNU (GNU GPL), znanej także pod nazwą copyleft. W odróżnieniu od tradycyjnego copyright, nakładającego na użytkownika szereg ograniczeń związanych z korzystaniem z oprogramowania, GPL pozwala na jego kopiowanie, rozpowszechnianie i modyfikowanie pod warunkiem dalszego licencjonowania na dokładnie takich samych warunkach.

30 Istnieją dwa główne systemy prawa autorskiego: anglosaski - czyli copyright i europejski, wywodzący się z francuskiego droit d'auteur. To ostatnie dzieli się na prawo osobiste i majątkowe. Prawo osobiste 
a więc treści należących do obszaru open access, a także wszelkich materiałów edukacyjnych, określanych mianem open education.

\section{Modele wydawania publikacji naukowych}

Obok tradycyjnego systemu wydawania publikacji naukowych istnieją dwa podstawowe modele publikowania w systemie open access. Przedstawiono je na rysunku 1.

Rysunek 1. Tradycyjny i nowy - otwarty system publikowania tekstów naukowych

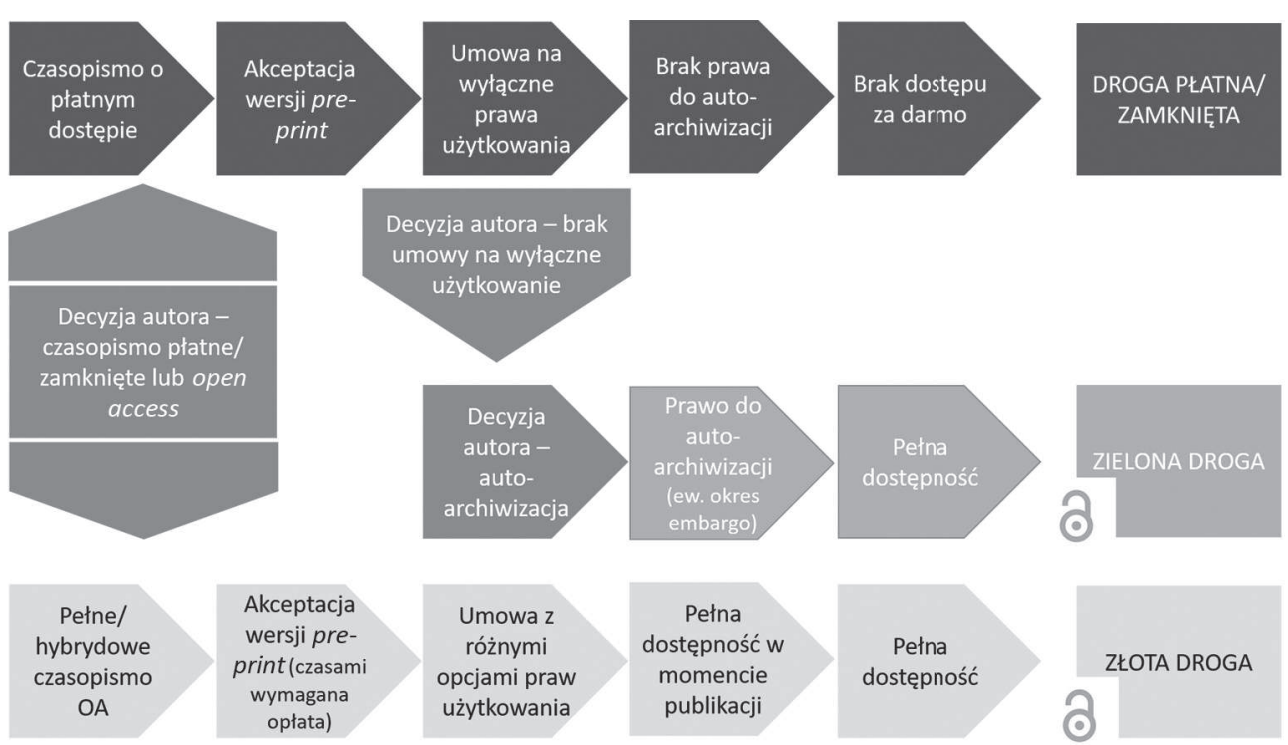

Źródło: Open Access at the Max Planck Society, https://openaccess.mpg.de/2365/en [dostęp 20.09.2013].

Schemat czerwony przedstawia system tradycyjny. Autor, naukowiec, przesyła swój tekst wydawnictwu. Jeśli zostanie on zaakceptowany, na podstawie umowy wydawnictwo przejmuje wszelkie prawa majątkowe do artykułu, co tym samym pozbawia

to prawo do autorstwa oraz do decydowania o ważnych dla interesu twórcy kwestiach, takich jak pierwsze rozpowszechnienie. Jest to prawo niezbywalne. Prawo majątkowe jest prawem zbywalnym i ma ograniczenia w czasie. Właścicielem praw według prawa autorskiego jest osoba fizyczna, podczas gdy w systemie anglosaskim copyright przyznawane jest producentowi lub wydawcy. Co ważne w kontekście open content, prawo autorskie ogranicza swobodne korzystanie z utworów, gwarantuje bowiem ich integralność, uniemożliwia wykonywanie kopii bez zgody właściciela i bez uiszczenia stosownej opłaty, zabrania tworzenia utworów pochodnych, np. tłumaczeń, a także rozpowszechniania bez powyższej zgody i opłat. 
autora nawet prawa do autoarchiwizacji. Później artykuł taki zostaje wydany w czasopiśmie, które wydawnictwo sprzedaje, najczęściej na zasadzie subskrypcji, bibliotekom, uniwersytetom i instytucjom badawczym. W systemie tym mamy do czynienia ze swoistym paradoksem, trzeba bowiem pamiętać, że naukowcy, inaczej niż twórcy literatury popularnej, nie otrzymują od wydawnictw wynagrodzenia za przekazywanie im praw majątkowych do swoich tekstów. Suber nazywa ich twórczość royalty-free literature ${ }^{31}$. Wynagrodzenie takie pochodzi najczęściej ze środków instytucji zatrudniających badaczy, bądź też z publicznych grantów. W przypadku niektórych dziedzin (np. medycyny) to naukowcy muszą wydawnictwu zapłacić za możliwość wydania artykułu, co sprowadza się do tego, że publikację finansuje instytucja zatrudniająca badacza, bądź też udzielająca mu grantu badawczego.

Funkcjonowanie powyższego modelu oparte jest na tzw. zasadzie publish or perish $^{32}$, rządzącej tradycyjnym systemem uprawiania nauki, w którym pokonywanie kolejnych szczebli kariery akademickiej oraz zdobywanie estymy w środowisku uzależnione jest od liczby i jakości publikacji naukowych wydawanych w liczących się w danej dziedzinie czasopismach. Gratyfikacją dla autorów jest tutaj sama możliwość publikacji. Czasopisma te są własnością wydawnictw, mających najczęściej status komercyjny. I tutaj dochodzimy do wspomnianego paradoksu polegającego na tym, że uczelnie i instytucje badawcze są zobowiązane płacić wydawnictwom komercyjnym za dostęp do treści, które wydawnictwa otrzymały za darmo od pracowników tychże uczelni i instytucji badawczych. W tej sytuacji nie może dziwić fakt, że według statystyk wskaźnik rentowności sprzedaży (ROS) dla działalności wydawniczej w obszarze publikacji naukowych, szczególnie w przypadku największych i najbardziej uznanych wydawnictw, sięga 30\% i jest jednym z najwyższych w sektorze ${ }^{33}$.

Internet, jako nowy kanał rozpowszechniania informacji, zaoferował możliwość publikowania treści naukowych w formie elektronicznej. Wykorzystały to oczywiście w pierwszej kolejności tradycyjne wydawnictwa, które, oprócz wersji papierowej, zaczęły publikować część artykułów również w formie cyfrowej. W ten sposób mogły one powiększyć rynek (czyli liczbę potencjalnych odbiorców), nie zwiększając przy tym znacząco kosztów, koszt krańcowy elektronicznej dystrybucji dąży bowiem do zera. Jednak dostępność rozpowszechnianych w ten sposób treści jest ograniczona, znajdują się one bowiem za tzw. zaporą. Oznacza to, że czytelnik chcący się zapoznać z daną treścią musi za nią zapłacić. Odnosi się to zarówno do odbiorców indywidualnych, płacących za pojedyncze artykuły (ich koszt może wynosić nawet 30 euro),

\footnotetext{
31 P. Suber, op.cit.

32 Publish or perish - publikuj albo giń.

33 M. Beaudouin-Lafon, Open access to scientific publications, „Communications of the ACM” February 2010, Vol. 53, No. 2, s. 32.
} 
jak i instytucji, które wykupują dostęp do baz z artykułami naukowymi na zasadzie subskrypcji. Mimo zmiany nośnika mamy tutaj cały czas do czynienia z tradycyjnym, zamkniętym systemem publikowania, czyli tzw. toll road ${ }^{34}$.

Rozwój globalnej sieci, a także rozpowszechnienie się tanich komputerów osobistych spowodowały również, że pojawiła się szansa na powstanie alternatywnego systemu publikacji treści naukowych poza tradycyjnym systemem wydawnictw. Przybrał on formę otwartych repozytoriów internetowych oraz internetowych czasopism, do których dostęp nie jest niczym ograniczony (czyli open access). Warto wspomnieć, że jedną z najbardziej aktywnych grup, które zaangażowały się w poszukiwanie nowych rozwiązań dotyczących publikacji naukowych, byli bibliotekarze, a wśród nich amerykańskie Association of Research Libraries (ARL). Z jego to inicjatywy w 1997 r. powostała Scholarly Publishing and Academic Resource Coalition (SPARC) - stowarzyszenie bibliotek i organizacji, którego celem jest opracowywanie nowych modeli dystrybucji tekstów naukowych ${ }^{35}$.

Pierwszą platformą publikującą teksty naukowe w otwartym systemie było arXiv. org, które powstało już w 1991 r. z inicjatywy amerykańskiego fizyka Paula Grinsparga. Początkowo publikowano w nim tzw. preprinty (czyli artykuły w formie roboczej, przed recenzją, inaczej mówiąc peer-review). Obecnie zawiera ono ponad 780 tys. tekstów naukowych z dziedziny fizyki, matematyki, informatyki, biologii kwantytatywnej, kwantytatywnych finansów i statystyki. Jest własnością Cornel University, prywatnej instytucji edukacyjnej non-profit ${ }^{36}$.

Jednym z najbardziej uznanych wydawców artykułów w systemie open access jest Public Library of Science (PLoS) ${ }^{37}$, którego powstanie zostało zainicjowane w $2000 \mathrm{r}$. przez trzech amerykańskich naukowców - noblistę Harloda Varmusa, Patricka Browna i Michaela Eisena. Od 2003 r. wydaje kilka czasopism, takich jak „PLoS Medicine”, „PLoS Computational Biology” czy też „PLoS Genetics”, z tekstami z zakresu medycyny i biologii. Za publikację w nich PLoS pobiera od autorów opłaty w wysokości do 2900 USD $^{38}$.

Kolejną amerykańską inicjatywą, która stała się globalnym przedsięwzięciem, jest Open Access Forum, założone w 1998 r., będące forum dyskusyjnym na temat open access. Przekształciło się ono w American Scientist Open Access Forum, a od 2012 r. funkcjonuje jako Global Open Access List. Na początku było ono moderowane

34 Toll road (toll - myto, opłata drogowa) - droga z mytem, co oznacza tutaj płatny dostęp do artykułów.

35 J. Hofmokl et al., Przewodnik po otwartej nauce, Interdyscyplinarne Centrum Modelowania Matematycznego i Komputerowego UW, Warszawa 2009, s. 17, http://ceon.pl/images/przewodnik_po_otwartej_ nauce.pdf

36 arXiv.org e-Print archive, http://arxiv.org/ [dostęp 29.09.2013].

37 M. Beaudouin-Lafon, op.cit., s. 33.

38 PLOS, http://www.plos.org/ [dostęp 29.09.2013]. 
przez Stevana Harnada, który jako jeden z pierwszych wyszedł z sugestią, by wszyscy autorzy archiwizowali swoje recenzowane artykuły w wolnym dostępie. To właśnie na tym forum dyskutowane są najważniejsze pomysły dotyczące rozwoju open access, takie jak autoarchiwizacja, repozytoria, kwestie cytowalności, praw autorskich czy też przemysłu wydawniczego. Inicjatywa ta stawia sobie za główny cel, by około 2,5 mln artykułów publikowanych rocznie w naukowych periodykach na całym świecie było rozpowszechnianych online w wolnym, otwartym dostępie ${ }^{39}$.

Open access stał się również przedmiotem zainteresowania Komisji Europejskiej, która w 2012 r. przedstawiła działania na rzecz poprawy dostępu do europejskich informacji naukowych, podkreślając, że otwarty dostęp przyczyni się do zwiększenia potencjału innowacyjnego Europy. Pierwszym z planowanych kroków było uczynienie wolnego dostępu do publikacji naukowych ogólną zasadą inicjatywy „Horyzont 2020", która jest unijnym projektem fiansowania badań naukowych i innowacji na lata 2014-2020. Wszelkie artykuły opracowywane przy wykorzystaniu środków $\mathrm{z}$ tego programu miały być udostępniane online przez wydawcę (tzw. złota droga), a także przez samych naukowców w otwartych archiwach (tzw. zielona droga). Jednym z zaleceń Komisji było również, aby państwa członkowskie przyjęły podobne podejście w stosunku do wyników badań finansowanych w ramach krajowych programów badawczych ${ }^{40}$. Dlatego także w Polsce MNiSW zadeklarowało, że otwarty dostęp do wyników badań finansowanych ze środków publicznych będzie jednym $\mathrm{z}$ priorytetów resortu nauki $\mathrm{i}^{41}$ na nadchodzące lata.

Badacze, którzy chcą rozpowszechniać swoje treści w sposób otwarty, mogą więc skorzystać, jak zostało to już wyżej wspomniane, z dwóch równoległych systemów, należących do modelu open access. „Złota droga” (golden road) oznacza recenzowane czasopisma open access, zaś „zielona droga” (green road) to otwarte repozytoria tekstów naukowych.

Proces umieszczania artykułu zgodnie z pierwszym modelem jest zbliżony do tradycyjnego. Autor przesyła swój tekst do czasopisma ${ }^{42}$, z którym podpisuje umowę,

39 GOAL Info Page, http://mailman.ecs.soton.ac.uk/mailman/listinfo/goal [dostęp 29.09.2013].

40 Dane naukowe: otwarty dostęp do wyników badań przyczyni się do zwiększenia potencjatu innowacyjnego Europy, Press Releases database, lipiec 17, 2012, http://europa.eu/rapid/press-release_IP-12-790_pl.htm [dostęp 29.09.2013].

41 Otwarta nauka - MNiSW - otwarty dostęp jednym z priorytetów na najbliższe lata, http://otwartanauka. $\mathrm{pl} / \mathrm{blog} / 2012 / 10 / \mathrm{mnisw}$-otwarty-dostep-jednym-z-priorytetow-na-najblizsze-lata/ [dostęp 29.09.2013].

${ }_{42}$ Warto wspomnieć, że istnieją dwa rodzaje czasopism open access: prawdziwe czasopisma open access (Genuine Open Access Journals), które udostępniają wszystkie teksty zgodnie z zasadami open access, oraz czasopisma hybrydowe (Hybrid Open Access Journals), w których tylko część tekstów jest umieszczana w wolnym dostępie, zaś pozostałe - wyłącznie w systemie tradycyjnym; por. Open Access at the Max Planck Society, https://openaccess.mpg.de/2365/en [dostęp 29.09.2013]. Modele hybrydowe polegają na tym, że wydawnictwo oferuje autorom lub instytucjom możliwość wniesienia specjalnej opłaty, która pozwoli 
przekazując mu tym samym prawa do artykułu. Jednak w tym wypadku przekazanie to nie ma charakteru licencji pełnej, warunki są ustalane pomiędzy stronami, zaś autor najczęściej zachowuje większość praw do utworu. Po przyjęciu do publikacji artykuł staje się dostępny online bez ograniczeń. Ważnym elementem całego procesu, co zbliża „złotą drogę” do modelu tradycyjnego, jest recenzowanie tekstu, które odbywa się zgodnie z przyjętymi tradycyjnie w nauce zasadami. Zasadniczą różnicą pomiędzy toll road a golden road jest więc kwestia dostępności dla odbiorcy końcowego, w pierwszym przypadku odbiorca płaci za treść, w drugim korzysta z niej bez opłat.

Jeśli chodzi o „zieloną drogę”, nazywaną inaczej autoarchiwizacją, polega ona na umieszczaniu na specjalnych platformach, zwanych repozytoriami, preprintów (czyli artykułów, które jeszcze nie zostały wydane) oraz tekstów, które wcześniej zostały wydane w systemie tradycyjnym. W tym wypadku archiwizacja ma miejsce bądź w tym samym czasie, co wydanie tradycyjne, bądź też z zachowaniem okresu embargo, narzuconego przez wydawcę pierwotnego, co oznacza publikację w repozytorium dopiero po upływie określonego czasu (np. miesiąc, sześć miesięcy, rok) od publikacji właściwej.

Poza tymi najbardziej uznanymi, istnieją również inne sposoby rozpowszechniania tekstów naukowych w wolnym (bezpłatnym) dostępie, takie jak osobiste strony www, e-booki, fora dyskusyjne, blogi, wiki itp. ${ }^{43}$

\section{Idea otwartości w kontekście motywacji}

Stallman w jednym ze swych esejów $\mathrm{w}^{44}$ przedstawiającym filozofię ruchu na rzecz wolnego oprogramowania stwierdza, że odbiorcy potrzebują wolności i współpracy, która jest ważniejsza niż prawo autorskie, a oprogramowanie płatne, które ma właścicieli, taką wolność i możliwość współpracy zabiera.

Wolny i otwarty charakter ma w rzeczywistości sama sieć. Ma ona rodowód publiczny, wywodzi się bowiem z wojskowego projektu ARPAnet. Poza tym pierwsze protokoły komunikacyjne (TCP/IP) umożliwiające działanie internetu, opracowane w ramach projektu naukowego na Uniwersytecie w Stanford, były darmowe ${ }^{45}$,

\footnotetext{
na opublikowanie tekstu w otwartym dostępie. Takie działania podejmują zazwyczaj tradycyjni wydawcy, którzy chcą przetestować model open access; por. J. Hofmokl et al., op.cit., s. 29.

43 P. Suber, op.cit.

44 R. Stallman, Free software, free society, 2010, s. 40, http://www.gnu.org/doc/fsfs-ii-2.pdf [dostęp 29.09.2013].

45 M. Castells, Galaktyka Internetu: refleksje nad Internetem, biznesem i społeczeństwem, Nowe Horyzonty, Dom Wydawniczy Rebis, Poznań 2003, s. 23.
} 
podobnie jak usługa internetowa www (world wide web), opracowana w CERN, której działanie oparte jest na publicznie dostępnych, otwartych standardach ${ }^{46}$. Wolność i otwartość są więc niejako immanentymi cechami internetu.

Można się zastanawiać nad tym, dlaczego zjawiska związane z wolnością i otwartością w sieci zyskały sobie tak wielkie rzesze zwolenników, bo sam charakter medium nie wydaje się czynnikiem wystarczającym. Według Maya źródłami skłonności do wolności i współpracy współczesnych użytkowników sieci mogą być: otwarty charakter samego internetu, który stał się głównym medium służącym rozpowszechnianiu informacji, w połączeniu z dwoma innymi, a więc wpływem zewnętrznych potrzeb na lokalne procesy polityczne oraz coraz bardziej oczywiste koszty ponoszone przez niektóre grupy społeczne z powodu wynagrodzeń przyznawanych innym grupom $\mathrm{z}$ tytułu praw własności intelektualnej ${ }^{47}$.

Wolny, otwarty internet jest bez wątpienia doskonałym narzędziem umożliwiającym podejmowanie rozmaitych działań o charakterze otwartym. Liczne badania takich zjawisk, jak wolne i otwarte oprogramowanie ${ }^{48}$ czy też produkcja partnerska ${ }^{49}$, których wspólnym mianownikiem jest dzielenie się $e^{50}$, wskazują jednak, że jedną z odpowiedzi jest również kwestia motywacji. W psychologii społecznej istnieje teoria motywacji wewnętrznych i zewnętrznych, wyjaśniająca w zadowalającym stopniu wymienione wyżej działania. Mówi ona, że osoby czyniące coś na rzecz innych robią to bądź ze względu na przyjemność i osobistą satysfakcję, jaką z tego czerpią (motywacja wewnętrzna), bądź też z powodu oczekiwanej nagrody, zapłaty, która może mieć charakter materialny, oznaczający pieniądze, jak i niematerialny, czyli na przykład dobrą opinię (motywacja zewnętrzna) ${ }^{51}$. Należałoby rozważyć, czy tego rodzaju wyjaśnienie jest adekwatne w stosunku do obu analizowanych tutaj zjawisk, a więc otwartej nauki oraz otwartej edukacji.

Wydaje się, że w przypadku otwartej nauki powyższa teoria znajduje w pełni swoje zastosowanie. Praca naukowców polega m.in. na podejmowaniu badań, opisywaniu ich i rozpowszechnianiu w postaci artykułów publikowanych w czasopismach naukowych. Jeśli założymy, że działalność naukowa jest pasją, chęcią odkrywania,

46 World Wide Web, Wikipedia, wolna encyklopedia, http://pl.wikipedia.org/w/index.php?title=World_ Wide_Web\&oldid=37464320 [dostęp 29.09.2013].

47 C. May, Bounded Openness. The future political economy of knowledge management, „European Intellectual Property Review" 2011, Vol. 33, No. 8, s. 477-480.

48 K. Lakhani, R.G. Wolf, Why Hackers Do What They Do: Understanding Motivation and Effort in Free/Open Source Software Projects, „SSRN Scholarly Paper”, Social Science Research Network, Rochester, NY, September 1, 2003, http://papers.ssrn.com/abstract=443040

49 Y. Benkler, op.cit.

50 P. Aigrain, Sharing: culture and the economy in the internet age, Amsterdam University Press, Amsterdam 2012, http://oapen.org/download?type=document $\&$ docid=409602

51 Por. Y. Benkler, op.cit. 
to niewątpliwie możemy uznać, że mamy tu do czynienia przede wszystkim z motywacją wewnętrzną. Dlatego bliskie będzie tutaj odniesienie do świata artystów i do powodów, dla których uprawiają sztukę. Analizował to m.in. Frey ${ }^{52}$, który podkreślał w tym kontekście motywację wewnętrzną opartą na przyjemności oraz na zobowiązaniu wobec społeczności, do której twórca przynależy. Badania naukowe są również podejmowane ze względu na motywy zewnętrzne, takie jak wynagrodzenie za pracę, bądź też budowanie wizerunku naukowca w środowisku, co z kolei wyjaśnia motywacja zewnętrzna $\mathrm{z}$ natychmiastową lub odroczoną zapłatą.

Jednak zasadnicza kwestia dotyczy nie tyle tworzenia, ile udostępniania prac w otwartym dostępie. W gruncie rzeczy, tak jak zostało to już opisane w poprzednich punktach, rozpowszechnianie treści naukowych bez gratyfikacji, a więc przekazywanie za darmo artykułów wydawnictwom do publikacji w czasopismach naukowych stanowiło podstawę funkcjonowania tradycyjnego systemu publikowania w nauce. Główną motywacją nie była tutaj zapłata o charakterze materialnym, ale niematerialna, mająca postać reputacji. W przypadku rozpowszechniania treści w systemie open access mamy do czynienia $\mathrm{z}$ dwojakim podejściem ze strony naukowców. Niektórzy, ze względu na renomę tradycyjnych czasopism, wolą pozostać przy starym systemie, który w ich opinii lepiej służy budowaniu wizerunku oraz wspomaga awans naukowy ${ }^{53}$. Motywacje pozostałych wydają się bardziej złożone. Warto tutaj uciec się do analogii z obszaru muzyki, a mianownicie dotyczącej motywacji użytkowników sieci wymiany plików muzycznych w internecie (tzw. pp). Badacze wyróżnili tam cztery motywacje do wymieniania się plikami: „dawanie jako realizacja”, „dawanie jako oczyszczenie”, „dawanie jako uczestnictwo”, „dawanie jako odnowa”" ${ }^{4}$. Szczególnie druga i czwarta zasługują tutaj na uwagę. „Dawanie jako oczyszczenie” oznacza sprzeciw uczestników analizowanych sieci wymiany wobec władzy koncernów, w tym wypadku fonograficznych, zaś „,dawanie jako odnowa” to rodzaj socjalistycznej, anarchistycznej i rewolucyjnej metafory ekonomii tych sieci, uwolnienie się od ograniczeń nałożonych przez stary system bazujący na sztywnym systemie copyright ${ }^{55}$. Użytkownicy podkreślali alternatywny sposób podejścia do statusu i wartości informacji, która powinna być wolna i dostępna dla wszystkich.

52 Por. R. Towse, Ekonomia kultury: kompendium, Kultura się Liczy!, Narodowe Centrum Kultury, Warszawa 2011, s. 328; C.D. Throsby, Ekonomia i kultura, Kultura się Liczy!, Narodowe Centrum Kultury, Warszawa 2010, s. 89.

53 Przykładowo w Polsce punkty uzyskane za publikację w określonych czasopismach pozwalają na uzyskanie kolejnego stopnia naukowego, liczą się też w rozmaitych konkursach na granty.

54 M. Giesler, M. Pohlmann, The Anthropology of File Sharing: Consuming Napster as a Gift, „Advances in Consumer Research" 2003, Vol. 30, s. 13.

55 Ibidem, s. 14 
Tego rodzaju sprzeciwu można się spodziewać wśród części naukowców będących zwolennikami open access, którzy nie chcą już dłużej pozostawać we władzy koncernów wydawniczych, będących właścicielami tradycyjnych czasopism. Jak zostało już wspomniane, publikacja $\mathrm{w}$ tradycyjnym systemie, choć uznana przez środowisko naukowe, ma jednak kilka niedogodności, takich jak chociażby przejmowanie od autora wszelkich praw, brak wynagrodzenia za takie przejęcie, a także ograniczony zasięg oddziaływania tekstów płatnych, do których dostęp jest coraz trudniejszy, coraz bardziej kosztowny ${ }^{5}$. Również idea wolności informacji, funkcjonującej poza systemem tradycyjnych praw autorskich, wydaje się skłaniać niektórych badaczy do zwrócenia się w kierunku systemów otwartych, które rozkwitły wraz z rozwojem internetu. Zresztą, jak podkreśla Castells, to właśnie kultura internetu bierze swój początek w „akademickiej tradycji wspólnego uprawiania nauki, reputacji opartej na merytorycznej jakości pracy naukowej, poddawania się ocenie środowiska naukowego i udostępniania wszystkich wyników badań wraz z podawaniem autora każdego odkrycia" ${ }^{37}$. Trudno się więc dziwić, że badacze są grupą, której idee wolności i otwartości internetu mogą się wydawać szczególnie bliskie.

W przypadku tworzenia zasobów edukacyjnych motywy wewnętrzne są równie istotnym czynnikiem co zewnętrzne. W badaniach motywacji autorów Wikipedij ${ }^{8}$ wyróżniono pięć kategorii powodów, dla których autorzy podejmują się redagowania wpisów. Są to:

- czynnik uczenia się (learning factor) - oznacza, że ludzie mają wewnętrzną potrzebę oraz chęć uczenia się i to daje im największą satysfakcję;

- czynnik flow - oznacza, że kiedy jakieś działanie polega na zabawie i czerpaniu z niej radości, mamy do czynienia z pewnego rodzaju „uzależnieniem”, chęcią kontynuowania zabawy, co może spowodować nawet utratę kontaktu z rzeczywistością; satysfakcja pochodzi z silnej koncentracji, „zaangażowania” w działanie, a także z samego działania;

- czynnik kreacji (creation factor) - oznacza, jak w przypadku artystów, chęć tworzenia, zrealizowania jakiegoś dzieła, a źródłem satysfakcji jest osiągnięcie tego celu;

- czynnik społeczny - oznacza potrzebę przynależności do grupy (odnajdujemy go na trzecim poziomie w piramidzie Maslova), a także oczekiwanie wzajemności; nagrodą dla każdego z uczestników przedsięwzięcia jest tutaj działanie dla dobra społeczności, powodowanie, że jest ona silna i aktywna;

- czynniki zewnętrzne - w postaci natychmiastowej lub odroczonej zapłaty.

\footnotetext{
56 Kwestia ta rozwinięta zostanie w dalszej części artykułu.

57 M. Castells, op.cit., s. 51.

58 H. Baytiyeh, J. Pfaffman, Volunteers in Wikipedia: Why the community matters, „Educational Technology \& Society" 2010, Vol. 13, No. 2, s. 131.
} 
Bliższa analiza pozwala stwierdzić, że wszystkie te motywacje wpisują się doskonale w wyżej przywołany, pierwotny schemat motywacji wewnętrznych i zewnętrznych, zaś autorzy badania dokonali po prostu bardziej szczegółowego podziału. Warto jeszcze przytoczyć w tym miejscu wypowiedzi samych uczestników na temat powodów, dla których przystąpili do projektu. Otóż wymienili oni pobudki altruistyczne, czyli pracę dla wspólnego dobra, chęć dzielenia się wiedzą z innymi i stworzenie powszechnie szanowanego źródła wiedzy wraz z innymi autorami. Mając na uwadze fakt, że autorzy Wikipedii tworzą swoje teksty anonimowo, wydaje się, że przeważają w tym wypadku pobudki wewnętrzne.

Jeśli chodzi o inne projekty otwartych zasobów edukacyjnych, to częstokroć są one realizowane przez rozmaite organizacje pozarządowe, finansowane w dużej części z pieniędzy publicznych. Biorą w nich udział wolontariusze, których motywacje można przyrównać do tych, jakimi kierują się twórcy Wikipedii, a więc altruizm, praca dla wspólnego dobra i stworzenie wartościowych materiałów dla innych. Skupiają się one wokół idei dzielenia się, jako wartości, będącego motorem innowacyjności. Ważna jest również świadomość, że materiały przygotowane przez daną osobę są dostępne na całym świecie, a praca nad nimi wraz z innymi członkami społeczności stanowi źródło przyjemności i satysfakcji ${ }^{59}$. Dla przykładu, projekt Wolne Lektury realizowany przez Fundację Nowoczesna Polska odbywa się dzięki pracy ochotników, nauczycieli i studentów, zaangażowanych we wspólny projekt ${ }^{60}$.

W projekty z tego obszaru angażują się także instytucje, chociażby uczelnie. Według analiz OECD wśród powodów takiego zaangażowania wymienia się chęć dzielenia się zasobami z krajami rozwijającymi się, wniesienia swojego wkładu we wspólne dobro, czy też włączenia się w lokalne, narodowe i międzynarodowe społeczności. Instytucje zdają się wierzyć, że dzielenie się wiedzą przyspiesza rozwój edukacji, stymuluje rozwój wewnętrzny instytucji oraz jest zachętą do innowacji ${ }^{61}$. MIT, uniwersytet będący jednym z inicjatorów ruchu otwartej edukacji, podaje następujące argumenty na rzecz przygotowywania i rozpowszechniania za darmo wykładów oraz rozmaitych materiałów do zajęć: chęć stworzenia dobrej jakości materiałów, umocnienia związków z absolwentami, lepszego przygotowania własnych studentów oraz rozwijania edukacji i poszerzania dostępu do niej ${ }^{62}$.

59 Giving Knowledge..., op.cit., s. 66.

60 e-wolontariat - Nowoczesna Polska zdobyła pierwsze miejsce, Fundacja Nowoczesna Polska, http:// nowoczesnapolska.org.pl/2011/01/20/e-wolontariat-nowoczesna-polska-zdobyla-pierwsze-miejsce/ [dostęp 29.09.2013].

61 Giving Knowledge..., op.cit., s. 64-65.

62 Ibidem, s. 63 . 


\section{Dyskusja wokół open access}

Według Przewodnika po otwartej nauce „w Stanach Zjednoczonych czy w Europie ruch open access można postrzegać w kategoriach reformy wymagającego zmian systemu dystrybucji literatury naukowej, jednak dla tak zwanych krajów rozwijających się wprowadzenie open access może oznaczać milowy krok w postępie naukowym"63. Hall zwraca uwagę na fakt, że świat nauki znajduje się obecnie w fazie istotnych przemian. Jest to spowodowane zmniejszeniem budżetów państwowych na rozwój i promowanie nauki z jednej strony i erozją tradycyjnego systemu publikacji - z drugiej ${ }^{64}$. Poza tym wydawnictwa naukowe ulegają procesowi koncentracji, $z$ dominującą pozycją na rynku takich międzynarodowych firm, jak Elsevier, Springer, Thomson czy Wiley ${ }^{65}$. Tendencja ta wpływa na wzrost cen subskrypcji, a także na przyjęcie modelu sprzedaży pakietowej przez duże podmioty. Polega to na tym, że do prenumeraty oferowane są pakiety czasopism, w których jeden lub dwa tytuły są rzeczywiście renomowane, zaś pozostałe mają znaczenie drugorzędne. W dodatku, wydając wiele czasopism, wydawnictwa mogą stosować korzyści skali, co utrudnia funkcjonowanie na rynku mniejszym podmiotom, szczególnie towarzystwom naukowym, będącym istotnymi ogniwami komunikacji między pracownikami nauki, które również wydają czasopisma.

Chavez podkreśla ${ }^{66}$, że od wielu lat nieustająco rosną koszty, jakie biblioteki muszą ponosić na zakup zarówno wydawnictw ciągłych, jak i książek i podręczników. Powołuje się na dane ARL (Association of Research Libraries), zgodnie z którymi członkowie tego stowarzyszenia odnotowali w latach 1986-2006 321\% wzrost wydatków na wydawnictwa ciągłe, podczas gdy wydatki na monografie wzrosły w tym samym okresie o $82 \%$. Przy czym liczba kupowanych tytułów czasopism wzrosła o 51\%, zaś monografii zaledwie o $1 \%$. Przy rosnących wydatkach zmniejsza się jednocześnie liczba wydawanych kopii, w 1996r. średnie nakłady wynosiły 1500 sztuk, zaś w 2006 r. - tylko 200-400. Potwierdzają to najnowsze badania opublikowane w „Library Journal", zgodnie z którymi biblioteki w różnych państwach na całym świecie wydają obecnie znacznie mniej środków na publikacje niż przed ostatnim kryzysem,

\footnotetext{
63 J. Hofmokl et al., op.cit., s. 42.

64 G. Hall, Digitize this Book. The Politics of New Media, or Why We Need Open Access Now, University of Minnesota Press, Minneapolis 2008, s. 42.

65 To największe wydawnictwa naukowe na świecie.

66 T.A. Chavez, Open-Access Publishing to Reduce the Cost of Scholarly Journals, „Numeracy” 2009, Vol. 3 , No. 1, s. 1, http://scholarcommons.usf.edu/numeracy/vol 3 /iss1/art8
} 
przy czym ceny publikacji i subskrypcji cały czas rosną ${ }^{67}$. Rosną również ceny subskrypcji baz danych z artykułami naukowymi. Dla przykładu, w latach 2005-2006 wzrosły one średnio o 6\%, zaś w latach 2006-2007 - o 8\% (w Niemczech aż o 14\%, zaś we Francji 9\% $)^{68}$.

Bezpośrednim skutkiem wzrostu cen jest rezygnacja bibliotek z zakupu części publikacji papierowych, a także dostępu online do baz danych $\mathrm{z}$ artykułami, co oznacza, że duża część naukowców, szczególnie z krajów rozwijających się, nie ma możliwości zapoznania się z najnowszymi wynikami badań i osiągnięciami naukowymi. Interesy wydawców oraz ich siła wynikająca $\mathrm{z}$ monopolu na treści niezbędne dla badaczy powodują, że potencjał wynikający z rozwoju internetu i w związku $\mathrm{z}$ tym malejących stale kosztów, w połączeniu z rozszerzającym się zasięgiem, nie może być $\mathrm{w}$ pełni wykorzystany ${ }^{69}$. W dodatku, co stwierdził senat jednego $\mathrm{z}$ amerykańskich uniwersytetów, podsumowując nasilający się kryzys w analizowanym obszarze branży wydawniczej, rosnąca kontrola ze strony wydawców komercyjnych publikacji i dystrybucji czasopism wydawanych przez uczelnie grozi erozją akademickich wartości, takich jak szybkie i szerokie promowanie nowej wiedzy oraz nieograniczony dostęp do wyników badań ${ }^{70}$.

W związku z powyższym rodzi się pytanie, czy open access mógłby być rozwiązaniem problemów w świecie publikacji naukowych. Niewątpliwie zmiana modelu publikowania z zamkniętego na otwarty przynosi wiele korzyści, takich jak ${ }^{71}$ :

- Dostęp do badań finansowanych z publicznych funduszy. Jest to argument bardzo często podnoszony w dyskusjach nad open access. W wielu krajach to właśnie sektor publiczny finansuje w przeważającej części pracę naukowców, dlatego wydaje się zasadne, aby podatnicy mieli dostęp do tych badań, na które przekazali środki.

- Większa dostępność artykułów i wyższa cytowalność. Ten argument wydaje się najsilniej przemawiać za otwartym dostępem, ponieważ artykuły opublikowane w ten sposób mają właściwie nieograniczony zasięg. Oznacza to więc większą liczbę czytelników i, w związku z tym, większe oddziaływanie.

67 S. Bosch, K. Henderson, The Winds of Change. Periodicals Price Survey 2013, 25 kwietnia 2013, http:// lj.libraryjournal.com/2013/04/publishing/the-winds-of-change-periodicals-price-survey-2013/ [dostęp 29.09.2013].

68 Online information drives growth - MARKET REPORT - Research Information, b.d., http://www. researchinformation.info/features/feature.php?feature_id=141 [dostęp 29.09.2013].

69 R.K. Johnson, Open Access: Unlocking the Value of Scientific Research, [zaprezentowano na:] The New Challenge for Research Libraaries: Collection Management and Strategic Access to Digital Resources Oklahoma 2004, s. 3, http://sparc.arl.org/sites/default/files/media_files/OpenAccess_RKJ_preprint.pdf

70 Ibidem.

71 Lista pochodzi z: J. Hofmokl et al., op.cit., s. 44-45. 
- Ułatwione wyszukiwanie informacji naukowych. Ze względu na to, że materiały udostępniane w wolnym dostępie są dokładnie opisywane za pomocą tzw. metadanych (np. słów kluczowych, roku, obszaru), łatwo jest je odnaleźć za pomocą ogólnych wyszukiwarek, takich jak Google. Trafiają one również, już w momencie umieszczenia ich w sieci, do międzynarodowych baz danych i serwisów naukowych.

- Udoskonalenie przepływu informacji. Cyfrowa forma oraz otwarty dostęp pozwalają na szybkie kopiowanie dokumentów i ich przesyłanie innym naukowcom, łatwo jest je również przechowywać w pamięci komputera i później przeszukiwać. Cały proces jest szybszy, tańszy i bardziej przyjazny środowisku.

- Promocja współpracy międzynarodowej i nowe możliwości interdyscyplinarnych przedsięwzięć naukowych. Tańszy oraz szybszy obieg informacji, a także ich nieeograniczony zasięg stymulują kontakty naukowe pomiędzy naukowcami z różnych ośrodków, sprzyjają również cyfrowemu włączaniu tych, którzy działają w ośrodkach dysponujących mniejszymi funduszami. Mamy tutaj do czynienia z prawdziwą globalizacją nauki.

- Zwiększenie wydajności procesu naukowego. Szybki i darmowy dostęp do informacji, możliwość łatwego przeszukiwania baz sprawiają, że proces badawczy może się znacznie skrócić.

- Możliwość zachowania praw autorskich do artykułów. W tradycyjnym systemie autorzy zobowiązywani byli najczęściej do przekazywania wydawnictwom pełni majątkowych praw autorskich. W systemie open access każdy autor sam decyduje o tym, jakiej licencji chce udzielić.

- Długoterminowe przechowywanie tekstów. Dzięki cyfrowej formie teksty w otwartych repozytoriach mogą być przechowywane długo i po znacznie niższych kosztach. Poza tym bardzo łatwo jest dotrzeć do rozmaitych materiałów archiwalnych. Do powyższej listy należy również dołączyć istotny argument o możliwości oceny artykułów naukowych przed ich oficjalną publikacją. Umożliwia to umieszczenie w repozytoriach open access preprintów, które, jako że są powszechnie dostępne, mogą zostać poddane konstruktywnej krytyce, co może się przełożyć na wzrost jakości takich tekstów oraz badań, na których sa oparte. Ważne jest również, że publikacja w repozytorium nie ogranicza autorów co do objętności, mogą więc oni zamieszczać w swoich tekstach bardziej szczegółowe analizy i wyniki, do których w tradycyjny sposób zazwyczaj nie można dotrzeć. Poza tym artykuły publikowane stanowią zaledwie część wszystkich zredagowanych tekstów, które z różnych względów, nie tylko merytorycznych (oceny peer review są subiektywne), nie zostały wydrukowane.

Wymienione argumenty są głównie natury niematerialnej. Podkreśla się tutaj dostępność informacji, łatwość wyszukiwania czy też zasięg. Warto jednak zaznaczyć, że rozpowszechnianie w systemie open access przekłada się również na wymierne 
korzyści finansowe. Po pierwsze, brak konieczności zakupu czasopism (prenumeraty) czy też dostępu do zamkniętych baz danych sprawia, że można dokonać bardziej efektywnej alokacji zasobów, w tym wypadku funduszy przeznaczanych na badania naukowe. Po drugie, łatwiejszy dostęp do informacji i jej szybszy obieg powodują, że skróceniu może ulec czas trwania różnych projektów naukowych i w związku z tym okres ich finansowania. Po trzecie, przechowywanie materiałów archiwalnych w formie cyfrowej jest tańsze niż magazynowanie ich w formie papierowej, oszczędności można również osiągnąć na etapie ich udostępniania.

W tabeli 2 przedstawiono korzyści z publikowania w systemie open access, jakie może odnieść przede wszystkim środowisko naukowe. Jedynie w pierwszym punkcie wspomina się o odbiorcach tekstów, którzy nie zaliczają się do tego środowiska, a którzy, jako podatnicy, finansują naukę. Tymczasem można wskazać również wiele innych korzyści z przyjęcia tego systemu, w podziale na poszczególne grupy beneficjentów.

Tabela 2. Korzyści z open access

\begin{tabular}{|c|c|}
\hline Grupa korzystająca & Korzyść \\
\hline Autorzy & $\begin{array}{l}\text { Możliwość dotarcia do odbiorców na całym świecie w większej liczbie niż mogłoby } \\
\text { to zagwarantować jakiekolwiek czasopismo zamknięte. Oddziałuje to na zwiększenie } \\
\text { widzialności badań, a także na wpływ prac na inne badania. }\end{array}$ \\
\hline Czytelnicy & $\begin{array}{l}\text { Możliwość uzyskania pozbawionego ograniczeń dostępu do literatury, jakiej potrzebują } \\
\text { do badań, który nie zależy od budżetów bibliotek. } \\
\text { Wolny od ograniczeń dostęp do oprogramowania, które jest stosowane przy wyszukiwaniu, } \\
\text { co pozwala na przeszukiwanie pełnych tekstów, indeksowanie, streszczanie, tłumaczenie, } \\
\text { linkowanie, rekomendowanie, informowanie. }\end{array}$ \\
\hline Nauczyciele i studenci & $\begin{array}{l}\text { Zarówno biedni, jak i bogaci mają dostęp do kluczowych źródeł wiedzy, brak jest też opłat } \\
\text { i specjalnych zezwoleń na kopiowanie i dystrybucję treści. }\end{array}$ \\
\hline Biblioteki & $\begin{array}{l}\text { Rozwiązanie kryzysu, z jakim mamy do czynienia, dotyczącego zbyt wysokich cen za } \\
\text { czasopisma naukowe. }\end{array}$ \\
\hline Uniwersytety & $\begin{array}{l}\text { Zwiększenie widzialności poszczególnych jednostek i ich badań, zmniejszenie wydatków } \\
\text { na czasopisma, sprzyjanie misji dzielenia się wiedzą. }\end{array}$ \\
\hline Czasopisma i wydawcy & $\begin{array}{l}\text { Zwiększenie widzialności artykułów, ułatwione dotarcie do publikacji ze strony odbiorców. } \\
\text { Większa łatwość przyciągnięcia reklamodawców, a także czytelników } \\
\text { oraz naukowców cytujących. }\end{array}$ \\
\hline Instytucje finansujące & $\begin{array}{l}\text { Zwiększenie zwrotu z inwestycji w badania, ponieważ wyniki są bardziej widoczne, } \\
\text { łatwiejsze do znalezienia, pozyskania i użyteczniejsze. }\end{array}$ \\
\hline Rządy & $\begin{array}{l}\text { Są często podmiotem finansującym badania naukowe, dlatego korzyści są podobne jak } \\
\text { w przypadku instytucji finansujących. }\end{array}$ \\
\hline Zwykli obywatele & $\begin{array}{l}\text { Dostęp do recenzowanych badań naukowych, które nie są najczęściej dostępne } \\
\text { w bibliotekach publicznych, a za które zapłacili oni w postaci podatków. }\end{array}$ \\
\hline
\end{tabular}

Źródło: Opracowanie własne na podstawie: P. Suber, Open Access Overview (definition, introduction), www. earlham.edu/ peters/fos/overview.htm [dostęp 29.09.2013]. 
Jak wynika z tabeli 2, korzyści ze stosowania systemu otwartego wykraczają znacznie poza te, które dotyczą bezpośrednio samych badaczy. Są one również istotne dla instytucji finansujących (grantodawców, w tym państwa, będącego często głównym podmiotem finansującym nauke, jak np. ma to miejsce w Polsce) oraz dla społeczeństwa, mogącego w łatwy sposób uzyskać dostęp do zamkniętych dotychczas danych, bądź też do tych, do których dostęp jest utrudniony. Finansowa korzyść może być również istotna w przypadku bibliotek funkcjonujących przy instytucjach naukowo-badawczych, ponieważ według szacunków koszt ich utrzymania co najmniej dwukrotnie przewyższa wydatki przeznaczane na zakup zbiorów ${ }^{72}$. Szerokie korzyści podkreśla również Houghton, stwierdzając, że publikowanie w systemie open access wpływa na zwiększenie zasobów użytecznej wiedzy, wzrost podaży wykwalifikowanych absolwentów i naukowców, tworzenie nowej naukowej aparatury i metod, rozwój sieci i pobudzenie społecznej interakcji, wzmocnienie zdolności rozwiązywania problemów, tworzenie nowych firm oraz dostarczanie wiedzy społeczeństwu ${ }^{73}$.

Chociaż publikacje wydawane w systemie otwartym są tańszą metodą rozpowszechniania wyników badań naukowych, nie należy zapominać, że wymagają również ponoszenia pewnych nakładów finansowych od wydających je jednostek. System ten może niewątpliwie wyeliminować takie koszty, jak druk, zarządzanie abonamentami, $\mathrm{DRM}^{74}$, marketing, a także wydatki na obsługę prawną ${ }^{75}$. Pozostałe koszty, takie jak koszty stałe, np. utrzymanie platformy archiwizującej artykuły, osób, które zajmują się obsługą, koszty redakcji i przygotowania tekstów do publikacji, a także recenzentów, w przypadku czasopism poddających artykuły peer-review, muszą być pokryte ze środków przeznaczonych na publikację. Dlatego też powstają różne modele biznesowe, dzięki którym jednostki (instytucje, wydawnictwa) wydające czasopisma naukowe mogą funkcjonować. Zostały one przedstawione w tabeli 3.

Nieco odmienną klasyfikację modeli biznesowych można znaleźć w Przewodniku po otwartej nauce (tab. 4).

72 P. Nowak, Rewolucja cyfrowa w komunikacji naukowej - szanse i zagrożenia, „Język, Komunikacja, Informacja” 2008, nr 3, s. 107.

73 J.W. Houghton, The costs and potential benefits of alternative scholarly publishing models, text, http:// informationr.net/ir/16-1/paper469.html [dostęp 29.09.2013].

74 Digital Rights Management - elektroniczne systemy, które pozwalają kontrolować sposób używania dzieł przez odbiorców (możliwość wykonywania kopii, przekazywania innym, drukowania, sposobu i liczby odtworzeń).

75 P. Suber, op.cit. 
Tabela 3. Modele biznesowe stosowane przez projekty open access

\begin{tabular}{|l|l|}
\hline \multicolumn{1}{|c|}{ Model } & \multicolumn{1}{c|}{ Opis } \\
\hline Reklama & Instytucje czerpią przychody z reklam. \\
\hline Darowizny & Instytucje mają stałe dotacje. \\
\hline Fund-rising & Instytucje zdobywają granty z fundacji. \\
\hline Hybrydowe czasopisma OA & $\begin{array}{l}\text { Instytucje opierają zysk na różnych przychodach od autorów i ich instytucji oraz } \\
\text { dodatkowo wydawca pokrywa koszty. }\end{array}$ \\
\hline Finansowanie przez instytucje & Instytucja stosuje bezpośrednie lub pośrednie dopłaty do publikacji czasopisma. \\
\hline Składki członkowskie & Przychody czasopisma pochodzą ze składek członkowskich. \\
\hline Wydania płatne & $\begin{array}{l}\text { Fundusze wykłada wydawca (większość numerów jest odpłatna, niektóre numery } \\
\text { są otwarte, np. starsze). }\end{array}$ \\
\hline Opłaty za publikację & Autorzy lub instytucje naukowe pokrywają koszty produkcji po publikacji. \\
\hline Opłaty za przyjęcie do publikacji & $\begin{array}{l}\text { Autorzy i instytucje wnoszą opłaty za przesłanie tekstu do redakcji, co nie jest } \\
\text { jednoznaczne z przyjęciem do druku. }\end{array}$ \\
\hline Praca społeczna & Czasopismo jest publikowane wysiłkiem społecznym. \\
\hline
\end{tabular}

Źródło: B. Bednarek-Michalska, Otwarta nauka, Open Access, Warszawa 2010, http://kpbc.ukw.edu.pl/dlibra/ docmetadata $? \mathrm{id}=52395 \&$ from=publication [dostęp 6.09.2012].

Tabela 4. Modele ekonomiczne otwartych publikacji

\begin{tabular}{|l|l|}
\hline \multicolumn{1}{|c|}{ Model } & \multicolumn{1}{|c|}{ Opis } \\
\hline Strona domowa & $\begin{array}{l}\text { Wydział uniwersytetu prowadzi strony domowe indywidualnych pracowników } \\
\text { naukowych, na których umieszczają oni swoje prace naukowe w otwartym dostępie. }\end{array}$ \\
\hline Archiwum e-printów & $\begin{array}{l}\text { Instytucja naukowa buduje i utrzymuje funkcjonowanie repozytorium, w którym autorzy } \\
\text { samodzielnie umieszczają własne teksty. }\end{array}$ \\
\hline Autor ponosi koszt publikacji & Opłaty ze strony autorów pokrywają koszty udostępnienia czasopisma w internecie. \\
\hline Subsydiowane & $\begin{array}{l}\text { Otwarty dostęp do czasopisma jest możliwy dzięki dofinansowaniu od zewnętrznej } \\
\text { instytucji. }\end{array}$ \\
\hline Model podwójny & $\begin{array}{l}\text { Zyski płynące z subskrypcji wersji papierowej finansują również dostęp online w wersji } \\
\text { open access. }\end{array}$ \\
\hline Dostęp z opóźnieniem & $\begin{array}{l}\text { Opłaty subskrypcyjne są pobierane za wydanie drukowane oraz natychmiastowy dostęp } \\
\text { do wersji cyfrowej. Dostęp open access do artykutów jest otwierany z opóźnieniem } \\
\text { (np. sześcio- lub dwunastomiesięcznym). }\end{array}$ \\
\hline Częściowy & $\begin{array}{l}\text { Tylko mała czéść artykułów z danego wydania jest wolno dosteppna, co służy celom } \\
\text { marketingowym. Dostęp do pozostałych artykułów posiadają tylko subskrybenci. }\end{array}$ \\
\hline Dla wybranych & $\begin{array}{l}\text { Open access jest oferowany studentom i naukowcom w krajach rozwijających się jako } \\
\text { forma wspierania ich rozwoju. Ta forma jest ograniczona i ściśle kontrolowana. }\end{array}$ \\
\hline Indeksy & $\begin{array}{l}\text { Dostęp jest otwarty jedynie do informacji bibliograficznej i abstraktów. Oferują go } \\
\text { agendy rządowe lub wydawcy (do celów marketingowych), którzy pobierają opłaty za } \\
\text { pełne teksty. }\end{array}$ \\
\hline Współdzielony & $\begin{array}{l}\text { Instytucje członkowskie (biblioteki, towarzystwa naukowe) wspólnie składają } \\
\text { się na rzecz utrzymywania czasopism open access i narzędzi umożliwiających } \\
\text { publikowanie zasobów. }\end{array}$ \\
\hline
\end{tabular}

Źródło: J. Hofmokl et al., Przewodnik po otwartej nauce, Interdyscyplinarne Centrum Modelowania Matematycznego i Komputerowego UW, Warszawa 2009, s. 28. 
Obydwie te klasyfikacje częściowo się zazębiają. W pierwszej z nich wskazuje się na możliwość finansowania publikacji z reklam. Model ten, zwany trójstronnym ${ }^{76}$, funkcjonował z powodzeniem w przypadku mediów tradycyjnych. Sprawdza się on również w przypadku finansowania treści publikowanych online, takich jak muzyka, filmy, programy telewizyjne czy artykuły prasowe. W przypadku publikacji naukowych sprawa jest znacznie trudniejsza, są one bowiem wydawnictwami niszowymi. Dlatego najczęściej finansowanie pochodzi z innych źródeł, takich jak środki publiczne czy prywatne, bądź też opłaty pochodzące od samych autorów za publikację lub za złożenie artykułu do publikacji. Coraz częściej więc zdarza się, że naukowcy włączają w budżety projektów naukowych sumy, jakie będą musieli zapłacić za wydanie wyników badań już w momencie składania wniosku o grant.

Może się wydawać, iż żądanie od badacza wniesienia opłaty wydawnictwu za możliwość opublikowania tekstu jest nadużyciem, jednak w niektórych dziedzinach, np. w medycynie, jest to praktyka powszechna. Dlatego też opłaty wnoszone na rzecz publikacji open access nie wydają się w tym kontekście nadmiernym ograniczeniem. Poza tym, jak wynika z badań A. Swan i S. Browna, sumy w jednym i drugim modelu są porównywalne ${ }^{77}$, co nie odbiera możliwości publikacji autorom funkcjonującym w takim właśnie, odpłatnym systemie. Bywa nawet, że o wiele droższa jest publikacja w czasopiśmie zamkniętym, dla przykładu opłata za artykuł w „Cell Reports” wynosi 5000 USD, zaś w „PLoS ONE”, a więc w najbardziej znanym wydawnictwie otwartym, tylko 1350 USD $^{78}$. Dlatego można poddawać w wątpliwość zasadność żądania opłat przez regularne czasopisma z dostępem zamkniętym od tych autorów, którzy chcieliby otworzyć dostęp do swojego artykułu.

Pojawiają się wprawdzie wydawnictwa oferujące publikację w systemie open access stosujące model pobierania opłaty od autora, których status wydaje się podejrzany, jak zostało to opisane w magazynie „Nature"79. Rzetelni badacze znają jednak zazwyczaj liczące się czaspisma ze swojej dziedziny, tak więc tego rodzaju zagrożenie nie powinno być istotne.

Beaudouin-Lafon krytykuje opisany model opłacania publikacji przez autora, uważając, że tylko bogate instytucje stać będzie na opłacenie wydań artykułów swoich pracowników, a to nie przyczyni się do zmniejszenia luki pomiędzy ośrodkami badawczymi z różnych krajów ${ }^{80}$. Tymczasem warto tutaj przywołać opinię Subera,

76 C. Anderson, Za darmo: przyszłość najbardziej radykalnej z cen, Społeczny Instytut Wydawniczy Znak, Kraków 2011.

77 A. Swan, S. Brown, Authors and open access publishing, „Learned Publishing” 2004, No. 17, s. 224.

78 R. Van Noorden, The True Cost of Science Publishing, „Nature” 2013, No. 495, s. 426-429.

79 S. Pincock, Open to possibilities, „Nature” 2013, No. 495, s. 539-541.

80 M. Beaudouin-Lafon, op.cit., s. 33. 
który podaje, że około 70\% czasopism open access nie żąda opłat od autorów, działają bowiem według innych, wymienionych wyżej modeli, za to aż około $75 \%$ wydawnictw tradycyjnych tego wymaga ${ }^{81}$, co stanowi jeszcze jeden argument na korzyść systemu open access. Na koniec zaprezentowanej argumentacji warto jeszcze przytoczyć wyniki badań porównawczych przeprowadzonych przez Houghtona w Wielkiej Brytanii, Holandii i Danii ${ }^{82}$, z których wynika, że korzyści ze stosowania modeli open access zdecydowanie przewyższają koszty, co w połączeniu z korzyściami niematerialnymi zdecydowanie przemawia za otwartym dostępem.

\section{Otwarte zasoby edukacyjne}

Jak zostało już wspomniane, jednym z najbardziej spektakularnych przykładów działań na rzecz tworzenia otwartych zasobów edukacyjnych i w związku z tym także najlepiej przebadanych projektów jest Wikipedia. Encyklopedię piszą jednostki, które nie otrzymują za swoją pracę żadnego wynagrodzenia. Co ciekawe, tworzenie artykułów jest tam w przeważającej części anonimowe (nieanonimowi są administratorzy). Benkler podkreśla, że „być może najbardziej interesującą cechą Wikipedii jest to, że ludzie ją tworzący są świadomi norm społecznych i potrzeby pisania w sposób obiektywny"83. Są to poza tym ludzie, którzy lubią pisać, co - według Benklera - w znacznej mierze uzasadnia ich chęć uczestniczenia w tworzeniu artykułów.

Inicjatyw z tego obszaru jest oczywiście znacznie więcej, chociaż są one mniej znane. Można wśród nich wymienić np. Projekt Gutenberg ${ }^{84}$, NASA Multimedia Collection $^{85}$, Teachers Without Borders ${ }^{86}$, OER Commons ${ }^{87}$, Khan Academy ${ }^{88}$, a w Polsce Biblioteka Cyfrowa Polona ${ }^{89}$, Platforma Akademii Orange ${ }^{90}$, Szkolna Biblioteka Internetowa Wolne Lektury ${ }^{91}$ czy też Włącz Polskę ${ }^{92}$. Inicjatywy tego rodzaju finansowane

81 P. Suber, op.cit.

82 J.W. Houghton, op.cit.

83 Y. Benkler, op.cit., s. 87.

84 http://www.gutenberg.org/wiki/Main_Page [dostęp 29.09.2013].

85 Ibidem.

86 http://teacherswithoutborders.org/resources\# [dostęp 29.09.2013].

$87 \mathrm{http} / / /$ www.oercommons.org/ [dostęp 29.09.2013].

$88 \mathrm{http} / /$ www.khanacademy.org/ [dostęp 29.09.2013].

$89 \mathrm{http}: / /$ www.polona.pl/dlibra [dostęp 29.09.2013].

90 http://www.akademiaorange.pl [dostęp 29.09.2013].

91 http://wolnelektury.pl [dostęp 29.09.2013].

92 http://wlaczpolske.pl/ [dostęp 29.09.2013]. 
są często przez międzynarodowe organizacje, np. UNESCO ${ }^{93}$, duże, międzynarodowe instytucje charytatywne, np. William and Flora Hewlett Foundation, Shuttleworth Foundation, Open Society Institute czy Trust for Civil Society in Central and Eastern Europe $^{94}$. Niekiedy wspierane są przez fundacje zakładane przez firmy, np. Fundacja Orange w Polsce, bądź też przez organizacje pozarządowe, takie jak Fundacja Nowoczesna Polska. W tworzenie otwartych materiałów edukacyjnych angażują się także uczelnie, np. amerykańskie Massachusetts Institute of Technology, Harvard czy Berkley, z kolei w Europie projekty tego rodzaju są niekiedy finansowane ze środków UE, czego przykładem może być chociażby Fizyka wobec wyzwań XXI w. - Uniwersytet Warszawski ${ }^{95}$.

Tego rodzaju model biznesowy, a więc opierający się przede wszystkim na działaniach wolontariuszy, finansowany ze środków publicznych, bądź też ze środków rozmaitych fundacji, nie wzbudza takich kontrowersji i dylematów, jak system open access. Do konfliktu dochodzi wówczas, gdy zagrożone zostają interesy prywatnych przedsiębiorstw. Przykładem takiej sytuacji w Polsce była decyzja rządu o wspieraniu e-podręczników i przeznaczeniu na ten cel sporych funduszy ${ }^{96}$.

Zasadniczo panuje powszechna zgoda co do tego, że rozwijanie otwartych zasobów edukacyjnych to idea korzystna dla społeczeństwa. Działania te przyczyniają się do wyrównywania szans w skali całego globu, jeśli chodzi o dostęp do wiedzy i możliwości kształcenia, podnosi się jego jakość oraz zwiększa liczba osób uczących się. Otwarte materiały mogą stanowić cenne uzupełnienie nie tylko tych dziedzin, które są nauczane w szkołach w pierwszej kolejności, ale można je również rozszerzać o bardziej zaniedbane edukacyjnie obszary, takie jak taniec, malarstwo, muzyka. Ich niewątpliwą zaletą jest multimedialność, co wpływa na lepsze przyswajanie wiedzy, a także możliwość szybkiej aktualizacji. W ten sposób użytkownicy w różnym wieku mogą zdobywać dodatkową wiedzę i umiejętności, które odpowiadają ich specyficznym zainteresowaniom. Mogą się również dokształcać z nowych zagadnień, często niezbędnych w szybko zmieniającej się rzeczywistości, czemu tradycyjny system edukacji zazwyczaj nie potrafi sprostać. Dzięki otwartej edukacji społeczeństwo jest lepiej wykształcone, pracownicy mają wyższe kwalifikacje, tak więc pozytywnym efektem zewnętrznym analizowanego ruchu może być, w dłuższej perspektywie, większa szansa na znalezienie pracy, czyli zmniejszenie się stopy bezrobocia.

\footnotetext{
93 Projekt Biblioteka Literatury Polskiej w internecie: http://literat.ug.edu.pl/ [dostęp 29.09.2013].

94 J. Hofmokl et al., op.cit., s. 65.

95 http://fizykaxxi.fuw.edu.pl/ [dostęp 29.09.2013].

96 Otwarte podręczniki pozbawia pracy 100 tys. ludzi? Oj, to chyba nie tak!, „Dziennik Internautów”, b.d., http://di.com.pl/news/48390,0, Otwarte_podreczniki_pozbawia_pracy_100_tys_ludzi_Oj_to_chyba_nie_ tak.html [dostęp 29.09.2013].
} 
Lepiej wykształcone społeczeństwo to także społeczeństwo bardziej świadome siebie i swojego funkcjonowania, mające większą tolerancję na różnorodność, odmienność oraz bardziej dbające o środowisko i zasoby naturalne, co może przełożyć się na lepsze gospodarowanie nimi. Otwarte zasoby edukacyjne mogą więc być jednym z ważniejszych czynników przyczyniających się do tego, by społeczeństwo funkcjonowało sprawniej.

\section{Podsumowanie}

Open access, a więc otwarta nauka i open education - otwarte zasoby edukacyjne to zjawiska, które zaczęły się rozwijać wraz z pojawieniem się internetu oraz z rozpowszechnieniem się komputerów osobistych i taniego, szybkiego dostępu do sieci. Dzięki nim znacząco zwiększył się dostęp do wiedzy, mamy do czynienia z prawdziwą tej wiedzy globalizacją. Skutkiem zaistnienia obu zjawisk jest szereg korzyści dla różnych interesariuszy działających w obu obszarach, począwszy od społecznych, a skończywszy na ekonomicznych.

Castells stwierdził, że „współpraca i swobodny dostęp do informacji bardziej sprzyjają innowacyjności niż konkurencja i ochrona własności intelektualnej" ${ }^{\prime \prime}$. Rzeczywiście, otwarty dostęp wpływa na zwiększanie zasobów użytecznej wiedzy, zarówno dla osób indywidualnych, jak i instytucji, co przeciwdziała nierównościom wynikającym $\mathrm{z}$ opłat za materiały naukowe i dydaktyczne istniejące $\mathrm{w}$ tradycyjnym systemie. Poza tym dzięki otwartości nie dubluje się badań realizowanych już gdzie indziej, co oszczędza czas, energię badaczy i - co ważne - pieniądze podatników. Prowadzi to do bardziej efektywnej alokacji zasobów pochodzących ze środków publicznych. Podobnie jest, jeśli chodzi o szybsze tempo wdrażania rozwiązań będących efektem prowadzenia badań naukowych, a także o realizację interdyscyplinarnych projektów między różnymi ośrodkami, co może mieć pozytywny wpływ na ogólny stan wiedzy i jej praktycznych zastosowań. Otwartość wpływa też pozytywnie na podaż wykwalifikowanych absolwentów i naukowców, pomaga tworzyć nowe metody edukacyjne, badawcze i wypracowywać innowacyjne rozwiązania także w biedniejszych ośrodkach naukowych. Lepszy dostęp do wiedzy i informacji przyczynia się do lepszego wykształcenia społeczeństwa i - w dalszej perspektywie - lepszego zrozumienia oraz traktowania otaczającego świata.

97 M. Castells, op.cit., s. 19. 
Ze względu na fakt, że ruch open access zaczął działać w otoczeniu, w którym wcześniej dominującą pozycję miały wielkie komercyjne wydawnictwa, zachwiał on ich dotychczasowym modelem biznesowym. Stał się korzystnym kierunkiem rozwoju, swoistym kołem ratunkowym dla przechodzącego kryzys uniwersytetu, w którym środki przeznaczane przez państwo na naukę sukcesywnie się zmniejszają, zaś koszty publikacji i dostępu do nich intensywnie i od wielu lat rosną. Szybszemu i bardziej efektywnemu rozwojowi tego ruchu bez wątpienia mogłyby pomóc działania ze strony państwa, takie jak lepsza polityka informacyjna adresowana do naukowców oraz stworzenie systemów faworyzujących publikacje w otwartym dostępie, a także ich znaczenie w uznawaniu awansu naukowego.

\section{Bibliografia}

About Ariadne, http://www.ariadne-eu.org/

About EADTU, http://www.eadtu.eu/about-eadtu.html

Aigrain P., Sharing: Culture and the Economy in the Internet Age, Amsterdam University Press, Amsterdam 2012, http://oapen.org/download?type=document\&docid $=409602$

Anderson C., Za darmo: przyszłość najbardziej radykalnej z cen, Społeczny Instytut Wydawniczy Znak, Kraków 2011.

arXiv.org e-Print archive, http://arxiv.org/

Bailey C.W., What Is Open Access?, w: Open Access: Key Strategic, Technical and Economic Aspects, s. 13-26, Chandos Publishing, Oxford 2006, http://www.chandospublishing. com/catalogue/record_detail.php?recordID $=103$

Baytiyeh H., Pfaffman J., Volunteers in Wikipedia: Why the Community Matters, „Educational Technology \& Society" 2010, Vol. 13, No. 2, s. 128-140.

Beaudouin-Lafon M., Open access to scientific publications, „Communications of the ACM” February 2010, Vol. 53, No. 2, s. 32-34.

Bednarek-Michalska B., Otwarta nauka, Open Access, Warszawa 2010, http://kpbc.ukw. edu.pl/dlibra/docmetadata?id=52395\&from=publication

Benkler Y., Bogactwo sieci: jak produkcja społeczna zmienia rynki i wolność, Wydawnictwa Akademickie i Profesjonalne, Warszawa 2008.

Budapest Open Access Initiative. Read the Budapest Open Access Initiative, http://www. budapestopenaccessinitiative.org/read

Butcher N., A Basic Guide to Open Educational Resources (OER), red. A. Kanwar, S. Uvalić-Trumbić, UNESCO, Vancouver, Paris 2011. 
Castells M., Galaktyka Internetu: refleksje nad Internetem, biznesem i społeczeństwem, Nowe Horyzonty, Dom Wydawniczy Rebis, Poznań 2003.

Chavez T.A., Open-Access Publishing to Reduce the Cost of Scholarly Journals, „Numeracy” December 31, 2009, Vol. 3, No. 1.

Dane naukowe: otwarty dostęp do wyników badań przyczyni się do zwiększenia potencjału innowacyjnego Europy, Press Releases database, 17 lipca 2012, http://europa. eu/rapid/press-release_IP-12-790_pl.htm

Déclaration de Paris sur les REL 2012, 2012, http://www.unesco.org/new/fileadmin/MULTIMEDIA/HQ/CI/CI/pdf/Events/French_Paris_OER_Declaration.pdf

Defining the "Open" in Open Content, http://opencontent.org/definition/

e-wolontariat - Nowoczesna Polska zdobyła pierwsze miejsce, Fundacja Nowoczesna Polska, http://nowoczesnapolska.org.pl/2011/01/20/e-wolontariat-nowoczesna-polskazdobyla-pierwsze-miejsce/

Giesler M., Pohlmann M., The Anthropology of File Sharing: Consuming Napster as a Gift, „Advances in Consumer Research” 2003, Vol. 30, s. 273-279.

Giving Knowledge for Free. The Emergence of Open Educational Resources, OECD, Paris 2007, http://www.oecd.org/edu/ceri/38654317.pdf

GOAL Info Page, http://mailman.ecs.soton.ac.uk/mailman/listinfo/goal

Grodecka K., Śliwowski K., Przewodnik po otwartych zasobach edukacyjnych, Koalicja Otwartej Edukacji, Warszawa 2012, http://koed.org.pl/wp-content/uploads/2012/03/ OZE_przewodnik_v4.pdf

Grossman L., You - Yes, You - Are TIME's Person of the Year, „Time” December 25, 2006, http://content.time.com/time/magazine/article/0,9171,1570810,00.html

Gurell S., Wprowadzenie do otwartych zasobów edukacyjnych, Koalicja Otwartej Edukacji, http://www.kpbc.ukw.edu.pl/Content/40051/gurell.pdf

Hall G., Digitize this Book. The Politics of New Media, or Why We Need Open Access Now, University of Minnesota Press, Minneapolis 2008.

Hofmokl J., Tarkowski A., Bednarek-Michalska B., Siewicz K., Szprot J., Przewodnik po otwartej nauce, Interdyscyplinarne Centrum Modelowania Matematycznego i Komputerowego UW, Warszawa 2009, http://ceon.pl/images/przewodnik_po_otwartej_nauce.pdf

Houghton J.W., The Costs and Potential Benefits of Alternative Scholarly Publishing Models, Text, http://informationr.net/ir/16-1/paper469.html

Johnson R.K., Open Access: Unlocking the Value of Scientific Research, [zaprezentowano na:] The New Challenge for Research Libraaries: Collection Management and Strategic Access to Digital Resources, Oklahoma 2004, http://sparc.arl.org/sites/default/files/media_ files/OpenAccess_RKJ_preprint.pdf

Lakhani K., Wolf R.G., Why Hackers Do What They Do: Understanding Motivation and Effort in Free/Open Source Software Projects, „SSRN Scholarly Paper”, Social Science Research Network, Rochester, NY, September 1, 2003, http://papers.ssrn.com/abstract $=443040$ 
May C., Bounded Openness. The Future Political Economy of Knowledge Management, „European Intellectual Property Review” 2011, Vol. 33, No. 8, s. 477-480.

Nowak P., Rewolucja cyfrowa w komunikacji naukowej - szanse i zagrożenia, „Język, Komunikacja, Informacja" 2008, nr 3, s. 103-119.

Online information drives growth - MARKET REPORT - Research Information, http:// www.researchinformation.info/features/feature.php?feature_id=141

Open Access at the Max Planck Society, https://openaccess.mpg.de/2365/en

Open Content, 28 stycznia 1999, http://web.archive.org/web/19990128224600/http://www. opencontent.org/home.shtml

Open Source - otwarte oprogramowanie, http://www.opensource.ite.pl/page/zalozenia.html

Otwarta nauka - MNiSW - otwarty dostęp jednym z priorytetów na najbliższe lata, http:// otwartanauka.pl/blog/2012/10/mnisw-otwarty-dostep-jednym-z-priorytetow-na-najblizsze-lata/

Otwarte podręczniki pozbawia pracy 100 tys. ludzi? Oj, to chyba nie tak!, „Dziennik Internautów", http://di.com.pl/news/48390,0, Otwarte_podreczniki_pozbawia_pracy_100_ tys_ludzi_Oj_to_chyba_nie_tak.html

Our History|MIT Open Course Ware|Free Online Course Materials, http://ocw.mit.edu/about/ our-history/

Pincock S., Open to possibilities, „Nature” 2013, No. 495, s. 539-541.

PLOS, http://www.plos.org/

Project Gutenberg, Wikipedia, the Free Encyclopedia, http://en.wikipedia.org/w/index. php?title=Project_Gutenberg\&oldid $=561202664$

Rankin J.A., Franklin S.G., Open Access Publishing, „Emerging Infectious Diseases” July 2004, Vol. 10, No. 7, s. 1352-1353.

Stallman R., Free Software, Free Society, 2010, http://www.gnu.org/doc/fsfs-ii-2.pdf

Suber P., Open Access Overview (definition, introduction), http://legacy.earlham.edu/ peters/fos/overview.htm

Swan A., Brown S., Authors and open access publishing, „Learned Publishing” 2004, No. 17, s. 219-224.

Tapscott D., Wikinomia: o globalnej wspótpracy, która zmienia wszystko, Cyberkultura, Internet, Społeczeństwo, Wydawnictwa Akademickie i Profesjonalne, Warszawa 2008.

The Winds of Change|Periodicals Price Survey 2013, http://lj.libraryjournal.com/2013/04/ publishing/the-winds-of-change-periodicals-price-survey-2013/

Throsby C.D., Ekonomia i kultura, Kultura się Liczy!, Narodowe Centrum Kultury, Warszawa 2010.

Towse R., Ekonomia kultury: kompendium, Kultura się Liczy!, Narodowe Centrum Kultury, Warszawa 2011.

Van Noorden R., The True Cost of Science Publishing, „Nature” 2013, No. 495, s. 426-429. 
What is the Paris OER Declaration?|United Nations Educational, Scientific and Cultural Organization, UNESCO, Communication and Information, http://www.unesco. org/new/index.php?id=64395\&L $=0$

World Wide Web, Wikipedia, wolna encyklopedia, http://pl.wikipedia.org/w/index.php? title=World_Wide_Web\&oldid=37464320

\section{Open access to knowledge: open scientific and educational resources in a knowledge based society}

Open on-line access to culture, knowledge and educational resources is an approach that allows different social and economic actors to profit in many ways, such as by reducing inequalities caused by access fees for scientific and educational materials, faster introduction of new solutions, creating possibilities of interdisciplinary projects uniting different participants. It is also an impulse of change in scientific and educational publishing.

Keywords: cultural industries, digital revolution, access, property, cultural policy

\section{Accès libre au savoir: les ressources scientifiques et éducatives libres dans la société basée sur la connaissance}

Accès "libre" ou autrement dit "ouvert" est le concept qui est devenu l'objet du débat, y compris scientifique, avec le développement de l'Internet. On parle d'un accès libre et ouvert aux biens de la culture, aux ressources de connaissance et aux ressources éducatives. Les initiatives qui ont commencé à se développer dans cet environnement favorable sont l'accès ouvert à la science, appelé open access (OA) et l'éducation ouverte, ou open educational resources (OER). Ceci a considérablement augmenté l'accès au savoir, ce qui entraîne de maintes avantages pour les différentes parties prenantes opérant dans ces deux domaines, autant sociaux qu'économiques. Il y a lieu de citer la lutte contre les inégalités qui résultent de frais des matériels scientifiques et didactiques dans le système traditionnel, une mise en œuvre plus rapide des solutions résultant des recherches scientifiques, la réalisation de projets interdisciplinaires par les différents centres, ce qui peut avoir un impact positif sur l'état général de la connaissance et de ses applications pratiques, et sur le nombre de diplômés et de chercheurs qualifiés. Un autre avantage 
est le lancement du processus de changement dans le secteur de l'édition, et plus particulièrement dans le domaine des publications scientifiques, où de grandes enseignes internationales occupaient jusqu'alors la position monopolistique. Ce changement peut avoir une influence positive sur le secteur de la science et de l'éducation, actuellement en crise.

Mots-clés: industries culturelles, révolution numérique, accès, propriété, politique culturelle

\section{Свободный доступ к знаниям: открытые научные и образовательные ресурсы в обществе, основанном на знаниях}

"Свободный" иначе "открытый" доступ — это термин, который с развитием интернета стал предметом дискуссии, в том числе научной. Рассуждается о свободном, открытом доступе к культуре, к знаниям и образовательным ресурсам. В этой благоприятной среде начали развиваться инициативы открытого доступа к науке - open access (OA), и открытых образовательных ресурсов - open educational resources (OER). Благодаря им значительно увеличился доступ к знаниям, результатом чего стало возникновение преимуществ для различных заинтересованных сторон, действующих в обеих областях, начиная от общественных и заканчивая экономическими. Они включают в себя противодействие неравенству, вытекающему из-за существующей в традиционной системе оплаты доступа к научным и дидактическим материалам, более быстрое внедрение результатов научных исследований, реализацию междисциплинарных проектов различными центрами, что может оказывать положительное действие на общее состояние знаний и их практическое применение, положительное влияние на поставку квалифицированных выпускников и исследователей. Другим преимуществом является начало процесса изменений в издательской отрасли, в частности это касается научных публикаций, монополизированных крупными международными субъектами. Это изменение может положительно отразиться на секторе науки и образования, находящемся сегодня в кризисе.

Ключевые слова: индустрия культуры, цифровая революция, доступ, собственность, культурная политика 